\title{
KARREN OF THE KAMENJAK HUM (DALMATIAN KARST, CROATIA); FROM THE INITIAL DISSECTION OF FLAT SURFACES BY RAIN TO ROCKY POINTS
}

\author{
ŠKRAPLJE HUMA KAMENJAK (DALMATINSKI KRAS, HRVAŠKA); \\ OD ZAČETNEGA OBDOBJA ČLENJENJA RAVNIH POVRŠIN \\ Z DEŽJEM DO SKALNIH KONIC
}

\author{
Martin KNEZ ${ }^{1,2}$, Josip RUBINIĆ ${ }^{3}$, Tadej SLABE ${ }^{1,2} \&$ Ela ŠEGINA ${ }^{4}$
}

\begin{abstract}
UDC 551.435.81(497.57)

Martin Knez, Josip Rubinić, Tadej Slabe \& Ela Šegina: Karren of the Kamenjak Hum (Dalmatian Karst, Croatia); from the initial dissection of flat surfaces by rain to rocky points

Rock relief is an important trace of the formation and development of karst phenomena on various carbonate rock. The existing current state is usually in a rich and diverse stage of homogeneous or heterogeneous development. The various forms of rock relief represent different ways and conditions a karst phenomenon formed and the developmental levels under the same conditions and with the same factors. Research into the connections between different developmental models is therefore necessary. Over time, not only rock relief but also rock forms begin to merge with one another. We are looking at the initial period of the development of a thick rock strata due to rain. On gently sloping rock strata, which tend to disintegrate at the edges, especially when they are inclined downwards, characteristic rock relief forms on the flat surfaces of larger planes, initially due to rainwater and sheets of creeping water and later through three-dimensional dissection and primarily the direct action of rainwater.
\end{abstract}

Keywords: karren, lithology, complexometry, rock relief, Lake Vrana, Croatia.
Izvleček

UDK 551.435.81(497.57)

Martin Knez, Josip Rubinić, Tadej Slabe \& Ela Šegina: Škraplje huma Kamenjak (Dalmatinski kras, Hrvaška); od začetnega obdobja členjenja ravnih površin $z$ dežjem do skalnih konic

Skalni relief je pomembna sled načina oblikovanja in razvoja kraških pojavov na različnih karbonatnih kamninah. Je pa zatečeno, trenutno stanje $\mathrm{v}$ največkrat bogatem in pestrem oblikovnem enovrstnem ali večvrstnem razvoju. Različna oblika skalnega reliefa torej predstavlja različne načine in razmere oblikovanja kraškega pojava in razvojne stopnje znotraj istih razmer in $\mathrm{z}$ istimi dejavniki. Zatorej je neobhodno proučevanje znotraj povezav v različne razvojne modele. Ne samo skalni relief, temveč tudi skalne oblike same se skozi čas prelivajo ena $\mathrm{v}$ drugo. Pred nami je začetno obdobje razvoja debelih skladov kamnine z dežjem. Na položnih skladih kamnine, ki na robovih, zlasti nagnjenih navzdol razpadajo, na njihovih ravnih površinah večjih ploskev pa se sprva $\mathrm{z}$ deževnico in s ploskovno polzečo vodo in nato s trirazsežnim razčlenjevanjem in predvsem neposrednim delovanjem deževnice oblikuje značilen skalni relief. Iz skalnih oblik, ki ga tvorijo, je moč natančno razbrati najbolj značilna obdobja razvoja škrapelj z odločilnimi dejavniki njihovega oblikovanja.

Ključne besede: škraplje, litologija, kompleksometrija, skalni relief, Vransko jezero, Hrvaška.

\footnotetext{
${ }^{1}$ Karst Research Institute, Research Centre of the Slovenian Academy of Sciences and Arts, Titov trg 2, SI-6230 Postojna, Slovenia and UNESCO Chair on Karst Education, University of Nova Gorica, Vipavska 13, SI-5000 Nova Gorica, Slovenia, e-mails: knez@zrc-sazu.si, slabe@zrc-sazu.si

${ }^{2}$ Yunnan University International Joint Research Center for Karstology, Xueyun rd. 5, CN-650223, Kunming, China, e-mails: knez@zrc-sazu.si,slabe@zrc-sazu.si

${ }^{3}$ University of Rijeka, Faculty of Civil Engineering, R. Matejčić 3, HR-51000 Rijeka, Croatia, e-mail: jrubinic@uniri.hr

${ }^{4}$ Miklošičeva 4a, SI-1230 Domžale, e-mail: ela.segina@gmail.com
}

Received/Prejeto: 05.01.2015 


\section{INTRODUCTION}

The exceptionally beautiful and interesting Dalmatian karst is a treasury of knowledge about karren, which dissect also the surface of the characteristic hum selected for this study.

Lithomorphogenetic studies of the karst surface comprise one of the foundations for understanding its formation and development.

The shape and development of the described karren testify to this. The rock forms that comprise the relief make it possible to accurately trace the most characteristic periods in the development of the karren and the decisive factors of its formation. The development model of the formation of bare rock exposed to rain is revealed from the flat and smooth rock to its dissection into points. The initial periods of the three-dimensional development of the rock are emphasized and described as part of the time model for the first time.

A wide variety of subsoil rock forms and forms carved by rainwater and creeping water were able to form on the uniform, fine-grained rock. The studied profile is dominated by heavily fissured pelmicrosparite limestone with a high calcium carbonate content. The layers vary in thickness from 50 to $120 \mathrm{~cm}$ and have a dip between $10^{\circ}$ and $15^{\circ}$. Numerous fissures, mostly in an east-west direction, have been widened many tens of centimeters by corrosion. All the strata react similarly to karstification.

\section{POSITION AND SHAPE OF KARREN}

The Kamenjak study area is situated in the coastal karst of Croatia in the immediate vicinity of Lake Vrana (Fig. 1). Its surface area of around $31 \mathrm{~km}^{2}$ makes it the largest freshwater lake in Croatia. The geological structure of the wider surrounding area of Lake Vrana consists of rocks dating between the lower period of the Upper Cretaceous (between limestone and dolomite $-\mathrm{K}_{2}^{1,2}$ ) and the Upper Neogene, as well as younger and mostly unconsolidated Quaternary sediments. The most frequently represented limestone dates in the upper part of the Upper Cretaceous $\left(\mathrm{K}_{2}^{3}\right)$ (Fig. 1) with well pronounced stratification and average strata thickness of $20-50 \mathrm{~cm}$. In these rocks, rudists are the most represented macrofossils and the percentage of carbonate in limestone is very high (95-99\%) (Strop, 2012). The study area is located in the coastal area of the Dinaric Mountains and belongs to the Outer Dinarides, or more precisely to the Ravna kotara unit in whose southeast part the outlet of Lake Vrana is located. The area displays folding in the northwest-southeast direction. In most cases the folds are tilted, sometimes flattened, and in the catchment of Lake Vrana they form scale-like structures. Fissures can be found as well, mostly longitudinal or reverse, and there are nappes, for example, to the north of Lake Vrana (Fritz, 1978). In terms of relief, the most distinctive limestone ridge is found just north of Lake Vrana with an approximately 300 meter difference in altitude between the highest parts of the ridge and the level of the lake. In the direction of Lake Vrana, the ridge tends to drop until it gradually disappears, its highest peaks being Štandarac (303 m.a.s.l.) and Bakrač (283 m.a.s.l.); the study area at the Kamenjak site lies at the altitude of around 250 meters.
From the viewpoint of climate, the area in the immediate vicinity of Lake Vrana has a mild Mediterranean climate with average monthly air temperatures varying between $5.9^{\circ} \mathrm{C}$ in January and $23.8^{\circ} \mathrm{C}$ in the warmest month of July and an annual average of $14.2^{\circ} \mathrm{C}$ based on the data from the Jankolovica meteorological station. The mean annual precipitation totals around 1,000 $\mathrm{mm}$, with the range of average monthly amounts between $17 \mathrm{~mm}$ (July) and up to $147 \mathrm{~mm}$ in November, the average wettest month (Magaš, 1990). The area is also characterized by periodic and very intense short-term precipitations that trigger periodic torrents at the outlet. Due to the hydrological characteristics of the terrain, underground run-off dominates despite the favourable climate conditions. The surface hydrological network is developed in areas composed of beds of Eocene flysch as well as on Quaternary sediments (Fig. 2).

Typical karst forms such as dolines are poorly developed here. Speleological objects such as caves are also relatively rare. They do exist, however, and the most important caves in the outlet include Baldina Cave, Banđenova Cave, Špilja near Vrana, and the 40-meter deep Jama na Kamenjaku cave that is found immediately next to the study area.

The immediate surroundings of the Kamenjak area were studied mostly from the hydrological and biological viewpoints relative to Lake Vrana (Fritz 1984, 1992, Kapelj et al., 2003, Mišetić \& Mrakovčić 2003, Švonja 2003, Mrakovčić et al. 2004, Romić et al. 2009, Šikić et al. 2013). A number of unpublished biospeleological studies in the karstic hinterland of the park have been done by the Lake Vrana Natural Park Authority (Mrakovčić et al. 


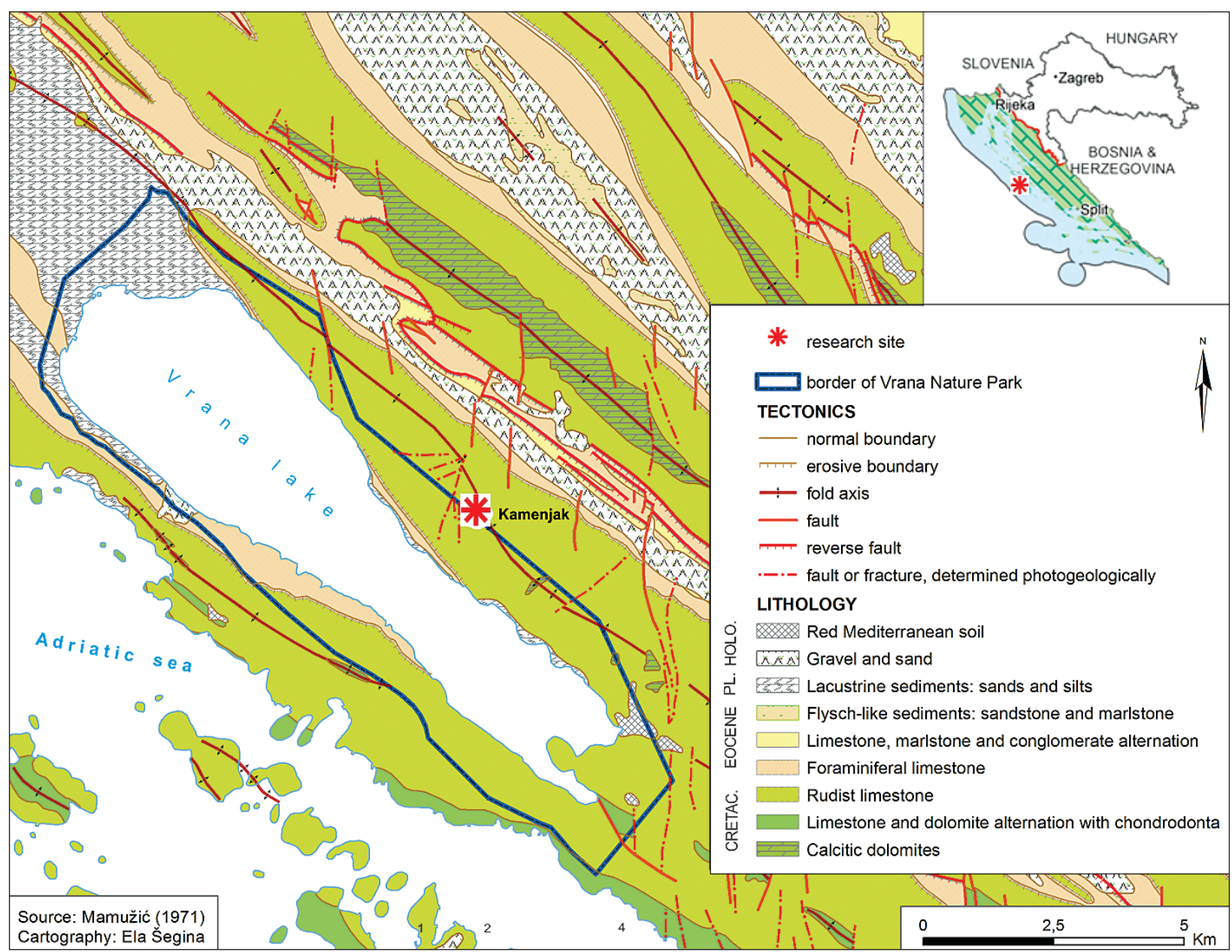

Fig. 1: Geological map with location of research site.

2004, Rađa \& Vujčić-Karlo 2004, Žvorc \& Hamidović 2008, Žvorc \& Hamidović 2010). The morphology of the karren in the wider coastal Dinaric area was studied by Rubić (1936) and later by Perica (1998), Perica et al. (1999), Perica et al. (2004), and Perica \& Marjanac (2009).

\section{KARREN FORMS}

The karren that dissect the wide top of the Kamenjak hum develop on inclined rock strata (Fig. 3). Except toward the southwest where it ends with a steep slope and walls, the hum has gentle slopes (it is higher in the sketch than in nature) (Fig. 4a). The slopes are distinctly dissected by karren, two thirds of which are sometimes densely but in most cases sparsely overgrown with shrub interspersed with large rock surfaces in most cases linked to the edges of rock strata. The karren are stepped (Fig. 4b, c) and the edges of the upper karren are several meters back from the lower ones. Along distinct bedding planes and vertical fissures the karren develop in three dimensions and are perforated by larger and accessible caves and smaller hollows. The surfaces of the rock steps are mostly flat, developed on larger blocks of rock strata, with only their edges able to disintegrate into medium and small size rocks. The tops of medium size rock steps in particular that are several decimeters wide tend to form into points and ridges (Fig. 4d, f) while the smallest disintegrate into gravel (Fig. 4e). The crumbling and sliding of rock and gravel downwards is more distinct at the edges that develop in the direction of the strata's dip (Fig. 4f) although the upper edges of strata also crumble (Fig. 4g). This is primarily dictated by the density of fissures in the rock, the thickness of strata, and the spacing of the strata along the bedding planes along which the rock slides downwards. Here the rock appears to be the most fractured. At the lower part of the top of the hum in particular, the fissures are filled with soil where shrubs grow.

Veress and Péntek (2010) clearly described the formation of a similar hum near Ploče. They described the influence of various rock strata that dictate the diversity in the formation of hums and the karren on them. 


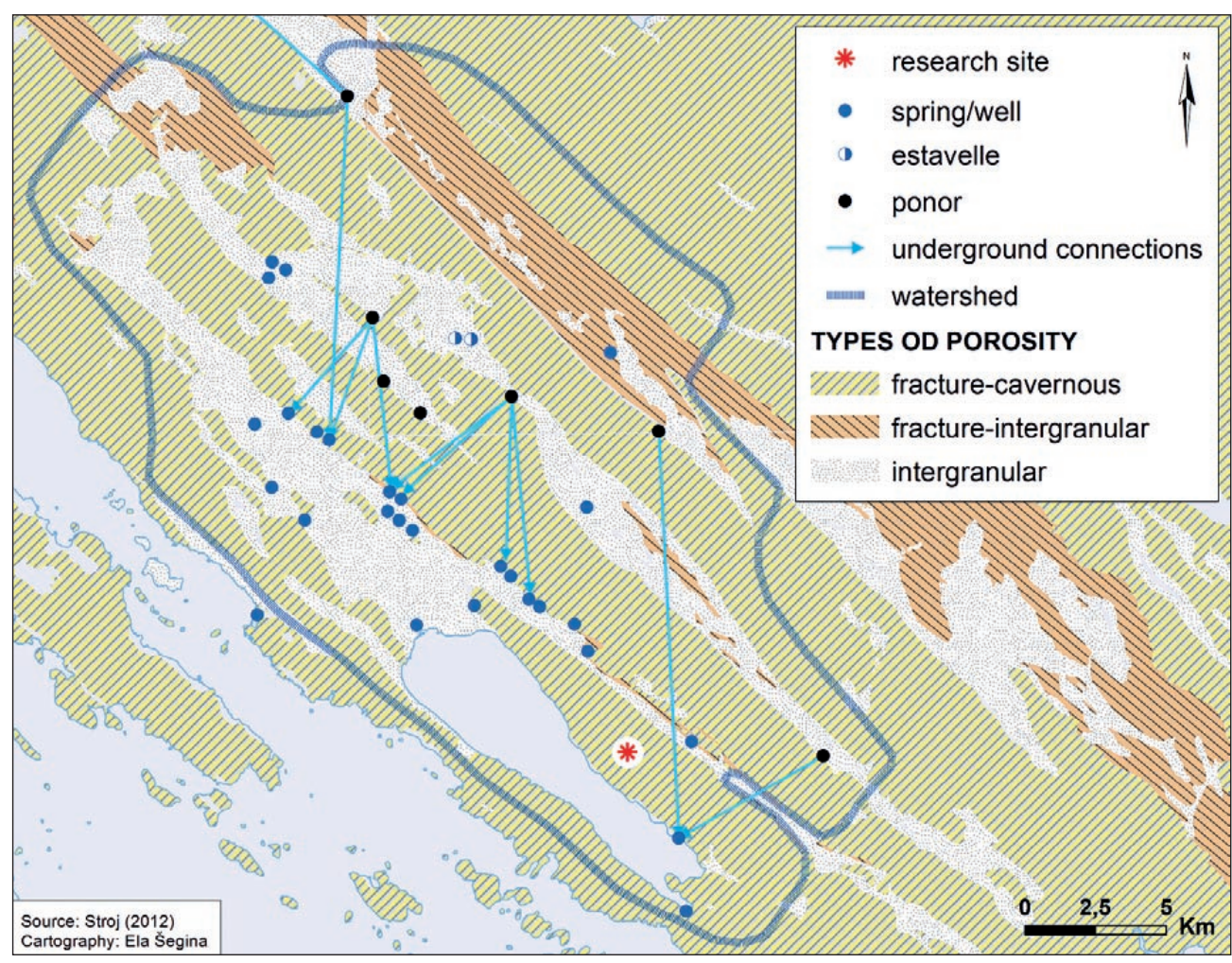

Fig. 2: Hydrogeological map with location of research site.

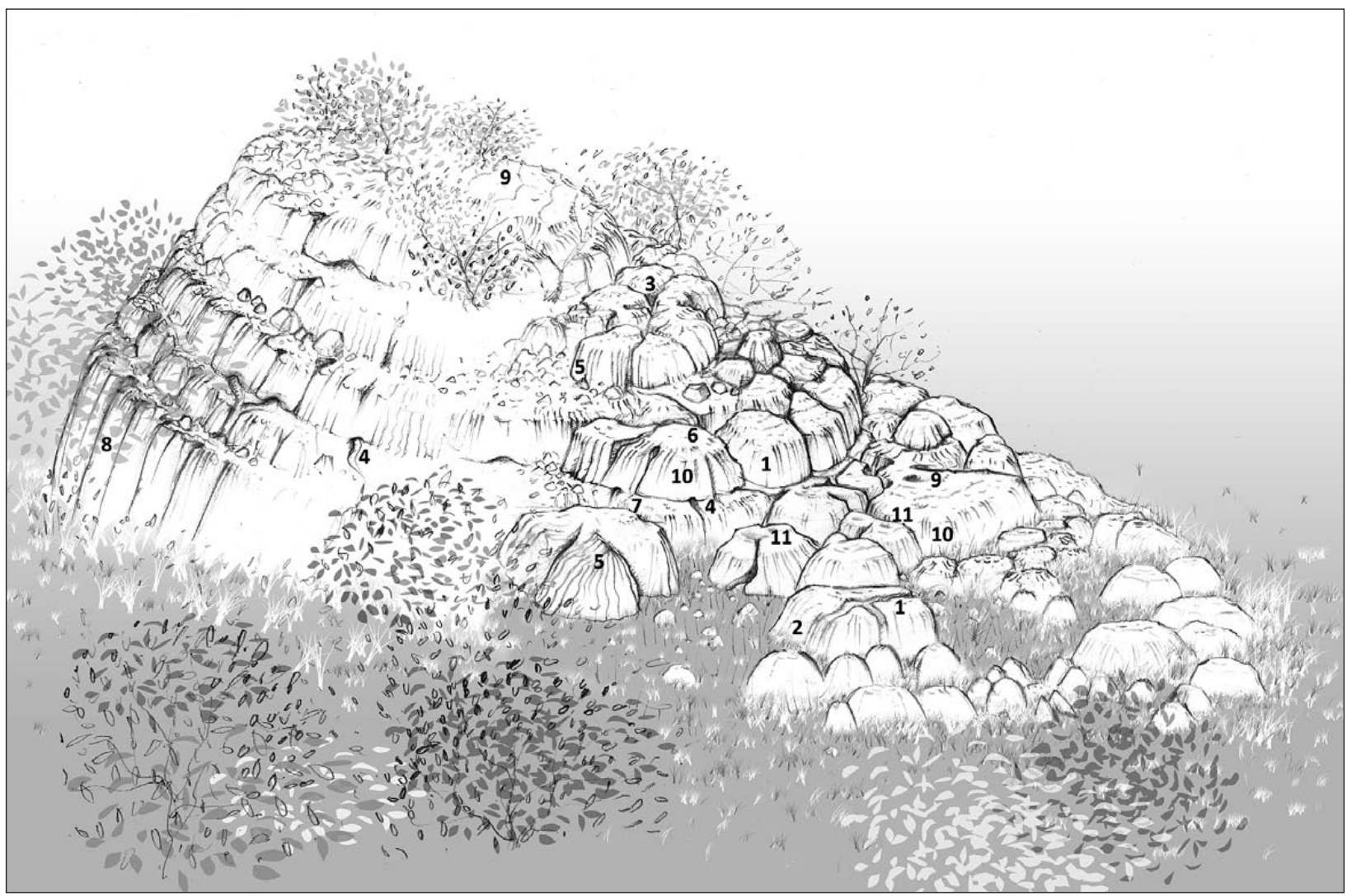

Fig. 3: Karren of Kamenjak hum: 1, 2 subsoil channels, 3 subsoil hole, 4 hole, 5 rain flutes, 6 shelf, 7 rain pits, 8 rain channels, 9 steps, 10 channels, 11 solution pan. 

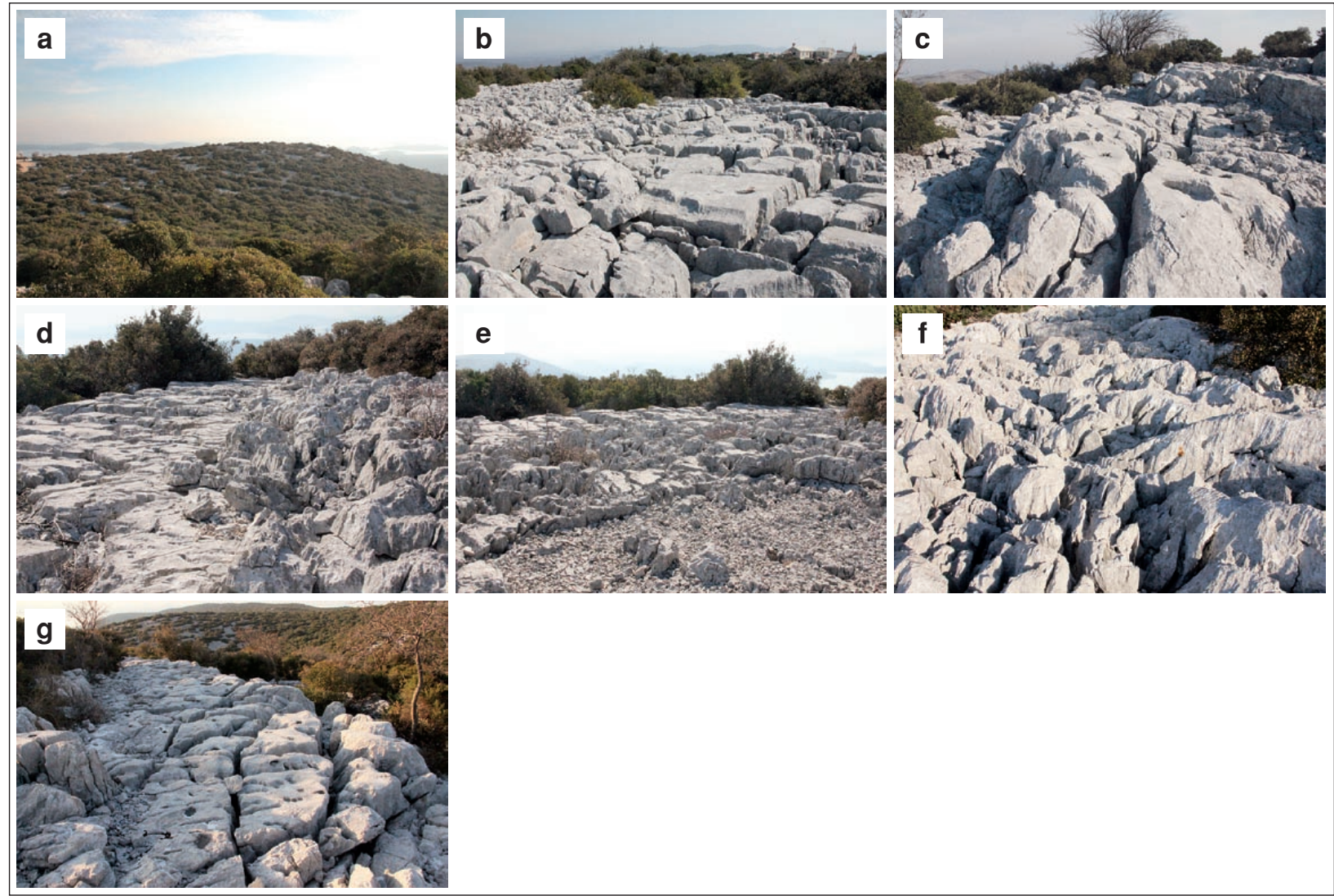

Fig. 4: Shapes of Kamenjak hum: a. hum, b.-e. shaping of the edge, f. lower edge, $g$. upper edge.

\section{GEOLOGY}

\section{MACROSCOPIC DESCRIPTION}

We studied the hum's upper fourteen limestone strata in the southwest-northeast direction in detail. With medium to thick strata between 50 and $130 \mathrm{~cm}$, the thickness sequence of the profile was $80,90,130,60,130,80,50,70$, $70,120,80,50,60$, and $70 \mathrm{~cm}$ from bottom to top. From the foot to the peak the dip of the strata varies only slightly, running predominantly toward the north and ranging between $10^{\circ}$ and $15^{\circ}$. The direction of strata dip is between $10^{\circ}$ and $15^{\circ}$. Strong fissuring is visible throughout the rock. Numerous, mostly subvertical faults, fault zones, fissures, and calcite veins are observed in all directions, predominantly in the east-west direction. In places the rock is bituminous. The rock is light brown, 5YR 7/2 prevails. The studied profile is 11 meters thick.

The lower three strata are homogenous and partly broken limestone; the edges of these strata are sharp and have not disintegrated. In places the fissures are oriented $300^{\circ}-120^{\circ}, 350^{\circ}-170^{\circ}, 275^{\circ}-95^{\circ}$, and $235^{\circ}-55^{\circ}$ and between the blocks of rock are widened in places up to $20 \mathrm{~cm}$. Strata 4 and 5 are heavily crumbled, the edges of the strata are blurred, and in places the rock has broken into one $-\mathrm{cm}^{3}$ pieces. The fissures oriented $355^{\circ}-175^{\circ}$, $235^{\circ}-55^{\circ}, 310^{\circ}-130^{\circ}, 290^{\circ}-110^{\circ}$, and $215^{\circ}-25^{\circ}$ have been widened by corrosion up to 5 to $10 \mathrm{~cm}$. The next three strata are again less disintegrated, although they are heavily broken and crumbling. Their edges are sharp. Along fissures oriented $295^{\circ}-115^{\circ}, 265^{\circ}-85^{\circ}$, $220^{\circ}-40^{\circ}, 300^{\circ}-120^{\circ}, 255^{\circ}-75^{\circ}, 230^{\circ}-50^{\circ}, 260^{\circ}-80^{\circ}$, and $175^{\circ}-355^{\circ}$ the rock is widened by corrosion, and along stronger fault zones it is crushed and crumbled into fine pieces. The ninth stratum is heavily crushed throughout its entire thickness with the majority of fissures running in a north-south direction. Toward the top of the profile there are heavily broken but uncrushed and undisintegrated strata. The numerous fissures are oriented $270^{\circ}-90^{\circ}, \quad 180^{\circ}-0^{\circ}, \quad 310^{\circ}-130^{\circ}, 215^{\circ}-35^{\circ}, 295^{\circ}-15^{\circ}$, $225^{\circ}-45^{\circ}$, and $250^{\circ}-70^{\circ}$. The division into four sections 
applied in the microscopic description is not visible in the macroscopic view.

Fifteen samples of the rock were taken from the profile and examined microscopically. Complexometric analyses were performed on all the samples (Tab. 1).

\section{MICROSCOPIC DESCRIPTION}

From 15 rock samples, 17 microscopic thin sections were prepared and examined in transmitted light. Prior to the microscopic examination, half of each sample was dyed in alizarin red dye (1.2-dihydroxyanthraquinone, known also as Mordant Red 11, Evamy and Sherman 1962). Combining the observations with the results of the complexometric titration analysis, we were able to determine the properties of the rock. Based on the thin sections, we divided the studied profile from the lithological aspect into four parts: the lower section is dominated by micrite to microsparite limestone with prevailing content of various largely micritized whole and fragmented foraminifers. The following second section of the profile is sparite limestone composed almost exclusively of peloids. The lower section of the upper half of the profile is mostly micrite limestone with various mostly whole and fragmented foraminifers and peloids. The upper section of the profile is composed of alternating layers of micrite, microsparite, and sparite limestone with foraminifers and peloids. Throughout this section of the profile the rock is very homogenous with a few tiny calcite veins.

Section one of the profile. Biopelmicrite limestone (wackestone to packstone) containing various foraminifers, ostracods, and pellets. In addition to bioclasts and pellets, individual micritized intraclasts with no internal structure and diameters up to $1.4 \mathrm{~mm}$ are observed.
Allochems in the rock occupy over $90 \%$ of the volume. Lamination is evident in places where areas of fine grains of calcite (up to $22 \mu \mathrm{m}$ ) alternate with micrite binder and areas of grains up to $45 \mu \mathrm{m}$ with microsparite binder. No bioclasts are found here. In general, the micrite binder, opaque and greyish to brownish in color, laterally passes with gradual transitions into microsparite binder. Individual fields of micrite or microsparite binder have diameters between 0.2 and $0.9 \mathrm{~mm}$. Clast sorting is not evident. As an exception, up to $0.3 \mathrm{~mm}$ large fensters filled with mosaic sparite calcite appear. The rock displays no signs of compaction, and there are no stylolites. In places the rock displays secondary porosity along younger fissures between 45 and $135 \mu \mathrm{m}$ wide. Sparite calcite has started to deposit on the walls of a part of the open fissure. The majority of the fissures up to $45 \mu \mathrm{m}$ wide are already filled by mosaic calcite.

Section two of the profile. Pelbiosparite limestone (grainstone) is typical in this section. Peloids, which constitute more than $90 \%$ of the rock, in places even more than $95 \%$, are of spherical, elliptical, and occasionally sharp-edged shapes. Due to heavy micritization of the rock, in many places the peloids continuously transform into carbonate matrix and the edges of peloids are blurred. They have no internal structure. The size of peloids is very uniform and ranges between 45 and $90 \mu \mathrm{m}$; peloids $90 \mu \mathrm{m}$ in diameter dominate. Due to the regular shape of peloids throughout the entire studied profile, we conclude that the peloids are pellets of faecal origin (Fig. 5). In addition to the pellets, the rock also contains other bioclasts. The prevalent types are large foraminifera, uniserial and biserial foraminifera, ostracods, and individual fragments of algae. Among the non-bioclastic

Tab. 1: Complexometric analyses of rock samples.

\begin{tabular}{|c|c|c|c|c|c|c|c|}
\hline $\begin{array}{l}\text { Rock } \\
\text { sample }\end{array}$ & $\begin{array}{c}\mathrm{CaO} \\
\%\end{array}$ & $\begin{array}{c}\mathrm{MgO} \\
\%\end{array}$ & $\begin{array}{c}\text { Dolomite } \\
\%\end{array}$ & $\begin{array}{c}\text { Total } \\
\text { carbonate (\%) }\end{array}$ & $\begin{array}{c}\text { Calcite } \\
\%\end{array}$ & $\mathrm{CaO} / \mathrm{MgO}$ & $\begin{array}{l}\text { Insoluble } \\
\text { residue }\end{array}$ \\
\hline 1 & 54,39 & 0,93 & 2,12 & 99,02 & 96,90 & 58,48 & 0,98 \\
\hline 2 & 54,34 & 0,93 & 4,24 & 98,92 & 94,68 & 58,43 & 2,08 \\
\hline 3 & 54,51 & 0,68 & 1,57 & 98,71 & 97,14 & 80,16 & 1,29 \\
\hline 4 & 53,66 & 0,44 & 2,03 & 96,69 & 94,54 & 121,95 & 3,31 \\
\hline 5 & 53,67 & 0,48 & 2,12 & 96,83 & 94,62 & 111,81 & 3,17 \\
\hline 6 & 53,72 & 0,48 & 2,21 & 96,88 & 94,67 & 111,92 & 3,12 \\
\hline 7 & 53,44 & 0,44 & 0,92 & 96,30 & 95,38 & 121,45 & 3,70 \\
\hline 8 & 54,62 & 0,44 & 2,03 & 98,40 & 96,37 & 124,14 & 1,60 \\
\hline 9 & 55,41 & 0,40 & 1,84 & 99,73 & 97,89 & 138,53 & 0,27 \\
\hline 10 & 54,68 & 0,56 & 2,58 & 98,76 & 95,18 & 97,64 & 1,24 \\
\hline $10 a$ & 54,23 & 0,32 & 1,47 & 97,45 & 95,98 & 169,47 & 2,55 \\
\hline 11 & 54,51 & 0,64 & 2,95 & 98,63 & 95,68 & 85,17 & 1,37 \\
\hline 12 & 55,40 & 0,52 & 2,58 & 99,96 & 97,38 & 106,54 & 0,04 \\
\hline 13 & 54,62 & 0,72 & 3,31 & 98,98 & 95,67 & 75,86 & 0,02 \\
\hline 14 & 55,01 & 0,68 & 3,13 & 100,00 & 96,87 & 80,90 & 0,00 \\
\hline
\end{tabular}


grains there are micritized intraclasts of irregular shapes between 0.9 and $1.4 \mathrm{~mm}$ in diameter and grains of pure calcite between 0.2 and $0.5 \mathrm{~mm}$ in diameter. No potential grain sorting can be observed. Throughout the entire section the cement is mostly mosaic drusy sparite. Drusy sparite with no internal structure also fills bioclasts. No compaction was observed in the rock. There is no porosity, and individual thin fissures of one generation perpendicular to the stratification and up to $20 \mu \mathrm{m}$ thick are filled with calcite. In places fissures pass into larger fensters between 0.9 and $1.8 \mathrm{~mm}$ in diameter. They are completely filled with mosaic drusy sparite whose crystals are from 90 to $135 \mu \mathrm{m}$ in size.

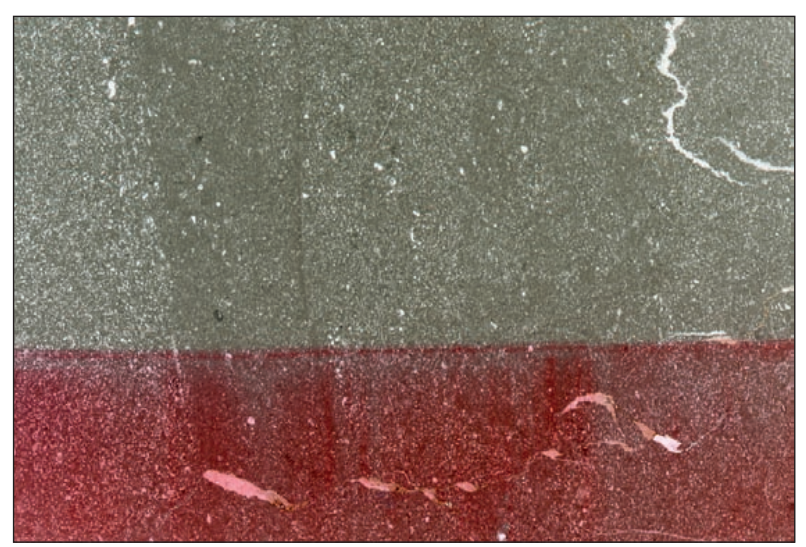

Fig. 5: Typical rock composed predominantly of peloids of regular shape (pellets of faecal origin). Sample was dyed in alizarin red dye.

Section three of the profile. The rock is biopelmicrite to pelbiomicrosparite limestone (wackestone to packstone). Among the bioclasts that comprise around $50 \%$, large foraminifera, uniserial and biserial foraminifera, ostracods, and fragments of algae dominate. Among the non-bioclastic grains there are numerous micritized intraclasts of irregular shape from 0.2 to $2.2 \mathrm{~mm}$ in diameter. Typical faecal pellets total between $25 \%$ and $30 \%$. Grains of pure calcite with diameters between 0.2 and $0.7 \mathrm{~mm}$ occur only exceptionally. There is no grain sorting. Micrite to microsparite cement that is opaque and greyish to brownish in colour with no evident porosity binds all the grains, while drusy sparite with no internal structure fills the bioclasts (ostracods and large foraminifera). No signs of compaction are observed in this section of the profile. Calcite veins of at least two generations are quite frequent, oriented across the bedding. The width of the calcite veins is between 15 and $45 \mu \mathrm{m}$, the majority $20 \mu \mathrm{m}$ wide. No slips along different generations of calcite veins are observed. Only one sample showed significant secondary porosity along a $0.5 \mathrm{~cm}$ wide crushed zone, already mostly filled with micritized mosaic drusy sparite.

The topmost section four of the profile has alternating strata of biopelmicrite, pelbiomicrosparite, and pelsparite limestone (packstone to grainstone) that contain foraminifera and ostracods. In addition to bioclasts, there are also individual micritized intraclasts without an internal structure and up to $1.5 \mathrm{~mm}$ in diameter. In some areas that change quite considerably laterally and vertically, faecal pellets are found most frequently. Allochems in the rock occupy around $80 \%$ of the volume. Micrite, microsparite, and sparite cement with no visible porosity bind all the grains. Micrite cement, greyish to brownish in color, gradually transforms laterally into microsparite cement. Drusy sparite with no internal structure fills larger bioclasts (ostracods and large foraminifera). No signs of compaction or grain sorting are evident. Strata of micrite limestone are substantially more broken and contain many calcite veins between 15 and $90 \mu \mathrm{m}$ thick from at least two generations distributed in various directions. Hardly any fissuring is observed in pelsparite limestone (grainstone). Along the fissuring secondary porosity in the rock occurs only exceptionally and to a lesser degree.

\section{COMPLEXOMETRIC TITRATION ANALYSES}

Using the dissolving method (Engelhardt et al. 1964) we performed 15 complexometric titration analyses on 15 rock samples (Tab. 1). We established that all the samples from the profile exceed $96.3 \%$ total carbonate. Four samples in the upper part of the lower half of the profile contain between $96 \%$ and $97 \%$ content of total carbonate, one between $97 \%$ and $98 \%$, seven between $98 \%$ and $99 \%$, and three samples between $99 \%$ and $100 \%$. The average value of all samples is $98.4 \%$. All of the samples show a high percentage of calcite. Only three samples had less than $95 \%$ calcite, and the average value of all samples is almost $96 \%$. All of the samples also contain a significant proportion of dolomite. Three samples have less than $2 \%$ dolomite, one less than $1 \%$, and only one between $4 \%$ and $5 \%$. The average value totals just over $2 \%$. Insoluble residue in the upper part of the lower half of the profile represents an important proportion in the carbonates. In four samples the value of insoluble residue slightly exceeds $3 \%$, and the average for all samples is $1.6 \%$.

\section{IMPACT ON KARSTIFICATION}

The entire geological profile including all the strata that form the peak of the hum responds similarly to karstification. 


\section{ROCK RELIEF}

\section{SUBSOIL ROCK FORMS}

Subsoil rock forms (Slabe \& Liu 2009) occur on the walls of crevices that developed along vertical fissures filled with soil where shrubs grow (Fig. 6a). On top of the hum there is less soil because most of it has been washed away, but more crevices are filled at the foot of the peak. On walls where smaller water currents flow in the crevices, individual channels around one decimeter in diameter develop (Fig. 3, 1). Some of these deepen and widen downwards forming half-bells while others have funnelshaped mouths. Subsoil channels around one $\mathrm{cm}$ in diameter beside one another on inclined walls and subsoil scallops on overhanging surfaces develop when water flowing into the crevice from a larger surface creeps relatively evenly along the rock at the contact with the soil. In the upper, three-dimensionally developed and denuded part of the karren, these forms are distinctly reshaped by rainwater and sheet flow water (Fig. 6b). Only at the foot of the peak where the crevices are still filled with soil is the rock in some places completely subsoil rounded and relatively smooth (Fig. 6c, d) and therefore denuded only recently. Here, only smaller surfaces of karren protrude from the soil. Subsoil channels (Fig. 3, 2) and pits that developed here and there under places covered with soil
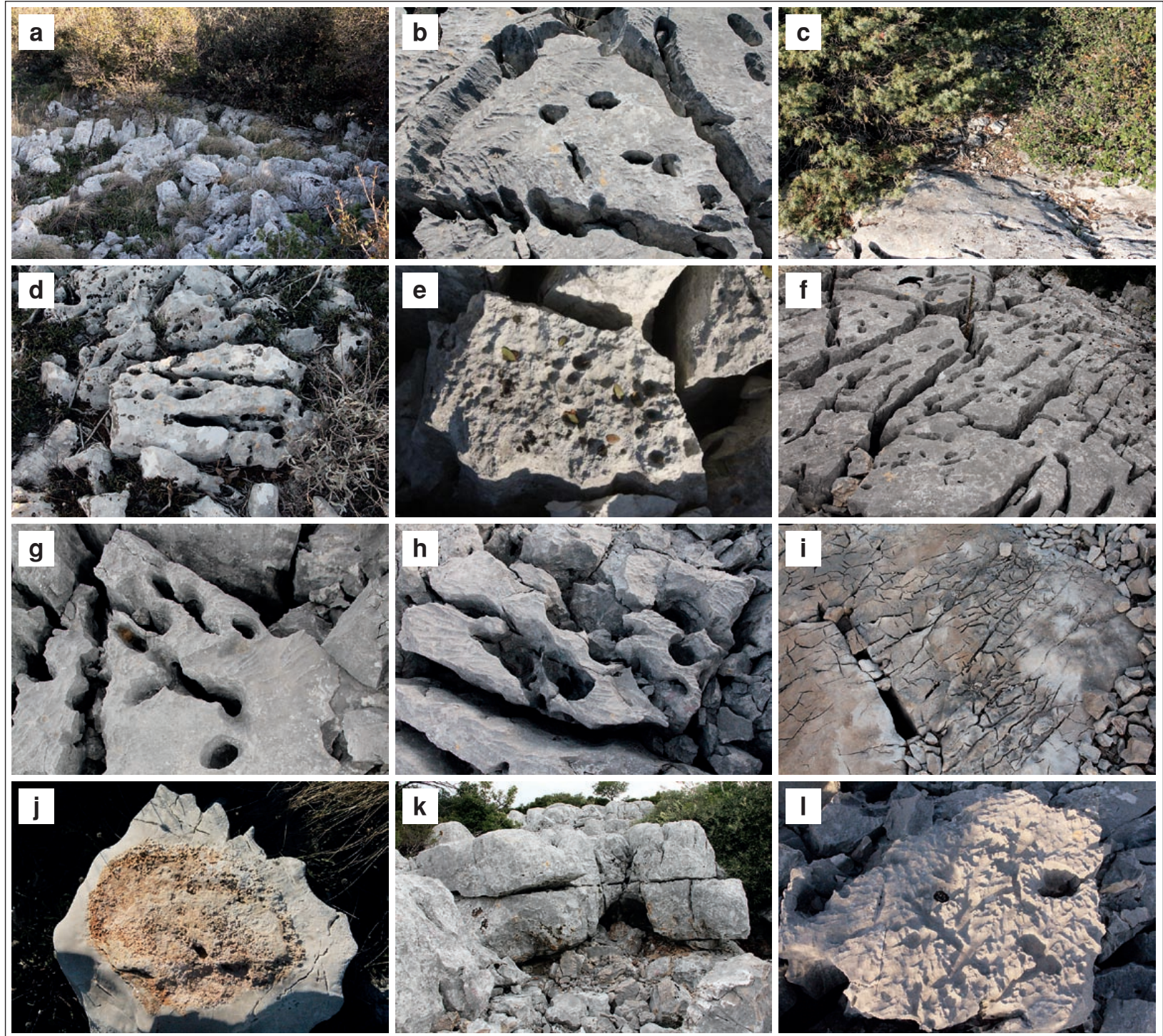

Fig. 6: Subsoil rock features: a. subsoil shaping of karren, b. subsoil rock features reshaped by rain, $c$., d. rounded subsoil rock, e. rain pits with humus, $f$., g., h. subsoil hollows, i. small channels along bedding plane, j. contact between beds of rock, $k$. hole along bedding plane, l. bedding plane channels reshaped by rain. 

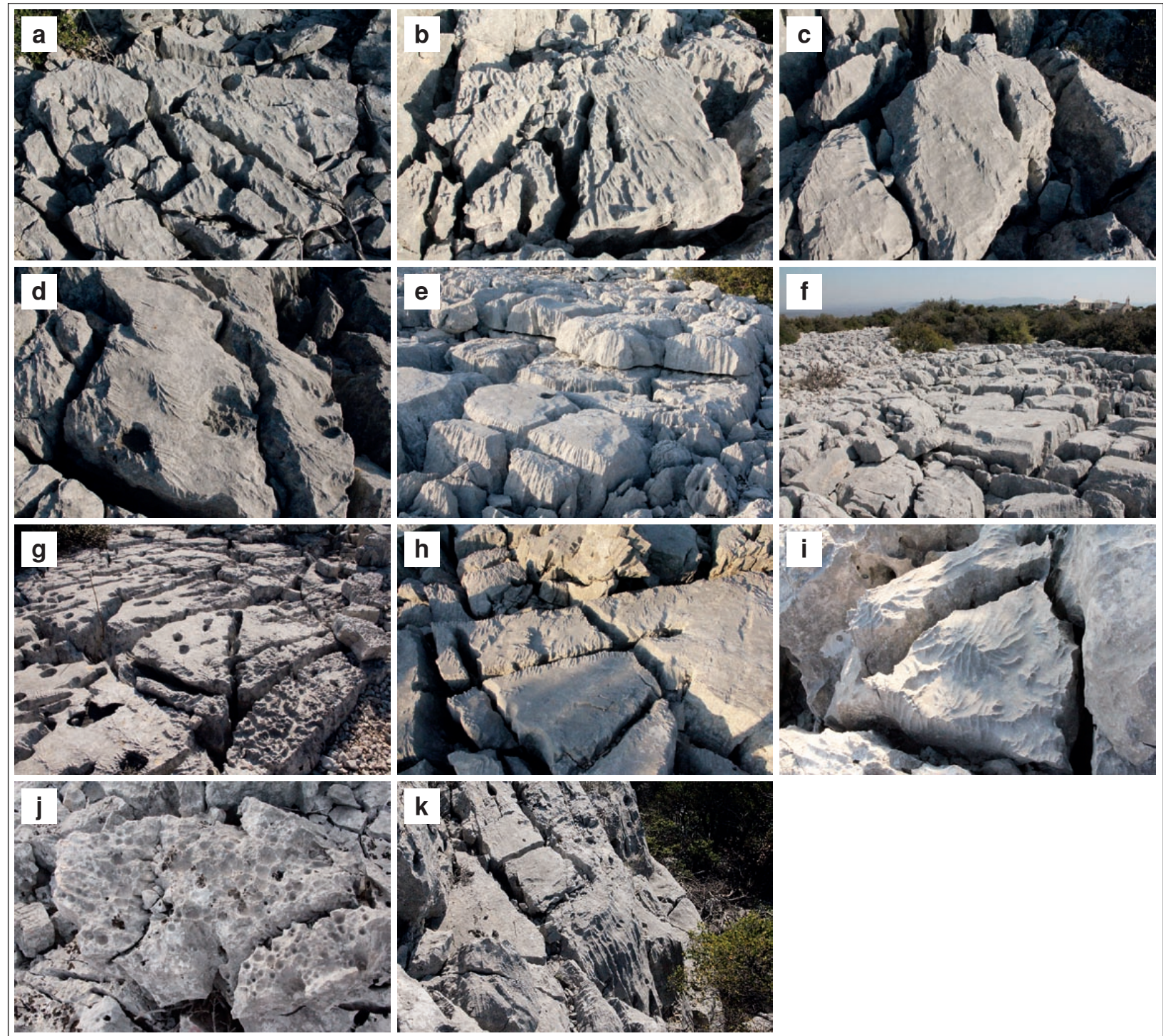

Fig. 7: Rock features carved by rain: a., b. rain flutes, c., d. rain flutes in upper and higher sides of the rock surface, e. rain flutes on sides of the karren, $f$. shelf, $g$. along bedding plane dissected surface, $h$. surface developed by sheet flow water, i. rain flutes on rock point, $j$. rain pits, $k$. rain channels.

are also relatively rare. When denuded, the pits transform into solution pans. Partial transformation also occurs in rain cups where weathered debris from fallen vegetation accumulates (Fig. 6e) and previously bare rock is overgrown with shrubs below which moss and lichen are often found.

The majority of the hollows along the fissures and bedding planes are also of subsoil origin. They have been denuded in the upper section of the karren. The diameters of hollows (Fig. 6f) along vertical fissures are measured in centimeters and decimeters. They stand individually or side by side along a dense network of fissures, most often in parallel rows (Fig. $6 \mathrm{~g}$ ) or perpendicular to them. Their cross-sections are either round or along fissures elliptical and distinctly elongated. They tend to merge leaving only thin and dissected remains of walls standing between them (Fig. 6h). In the upper sections of the karren there are cavities reshaped by sheet flow water and mouths that are becoming funnel-shaped with flutes at the circumferences also reshaped by rainwater (Fig. 3, 3). The water that percolates through them carves the lower lying rock strata. Meandering channels occur on the surface of the lower strata (Fig. 6i) and cups can form as well. Elsewhere the contacts are impermeable (Fig. 6j). Along bedding planes individual meandering holes (Fig. 6k) or bedding plane anastomoses formed above-sediment, so most of their cross sections are found in the upper stratum (Fig. 3, 4). Their diameters 

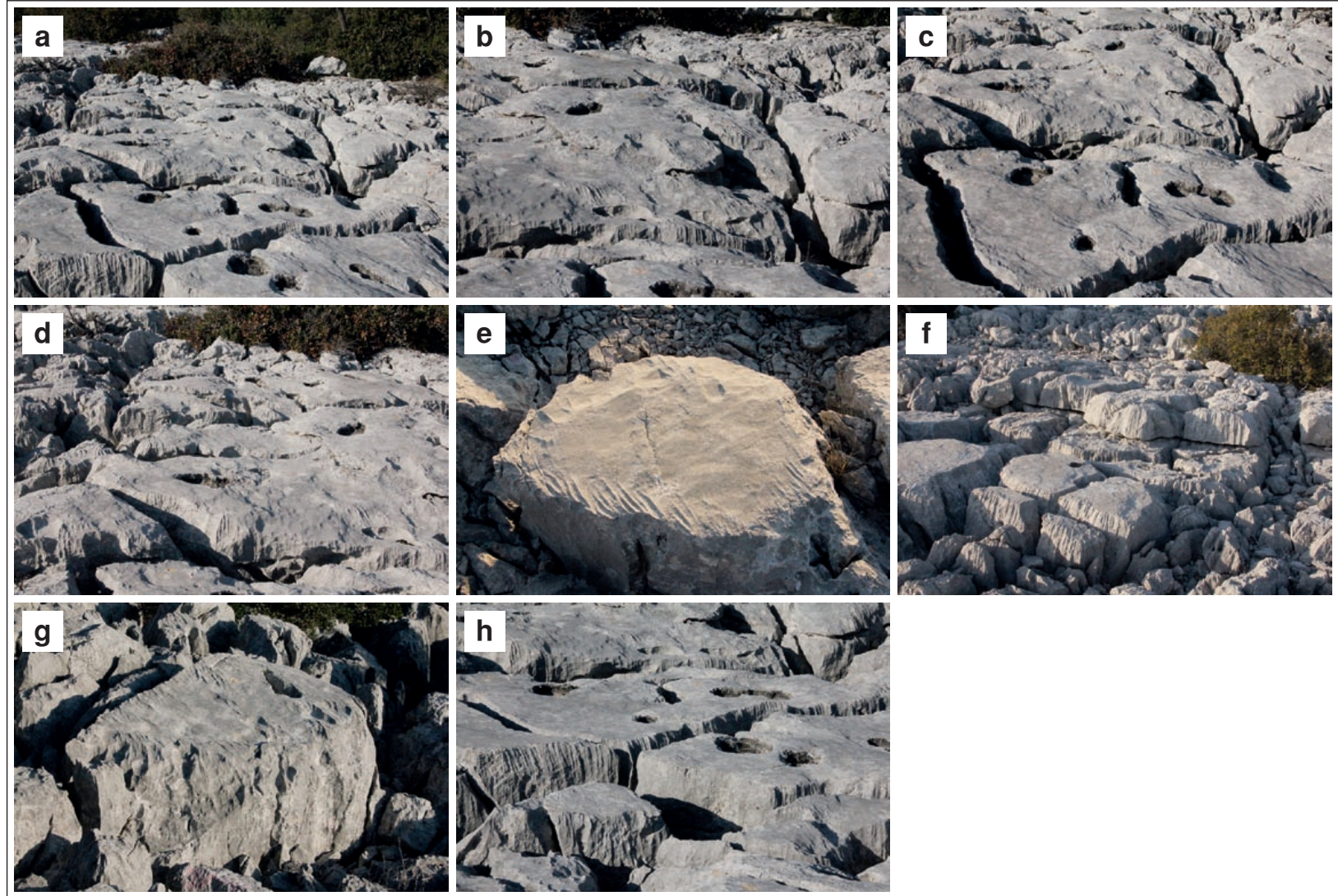

Fig. 8: Rock features developing by sheet flow water on the flats tops of karren: a., b., c., d., e., f. steps, g. rain flutes on the upper part of rock surface and steps below, $h$. channels.

range from a few millimeters to one meter or more. After the disintegration of the upper stratum of the karren, the small and meandering, formerly interbed channels cut into the upper surface of the formerly lower part of the stratum are revealed (Fig. 6l).

\section{TRACES OF RAINWATER AND SHEET FLOW WATER}

On distinctly inclined rock surfaces, rainwater carves rain flutes (Fig. 3, 5). On sections of karren that narrow upwards into a point or a ridge, for example, on smaller rocks, they are found over the entire surface (Fig. 7a, b). As a rule, they occur most frequently on the upper section of the stratum that was first denuded and exposed to rain (Fig. 7c, d). The surface below them is smooth. They also form on the steep edges of karren, the upper parts of crevice walls, and on inclined surfaces of more extensive and predominantly flat tops (Fig. 7e). After the upper rock stratum disintegrated, belts of flutes are preserved at the edges of former wider lower and currently upper strata that occurred as a part of the uniform flutes that once ran from the former peak. Only sections of the upper stratum remained in individual places. Such rocks, which are smaller and therefore in most cases pointed and dissected by flutes, protect the lower stratum from the direct impact of rain. The rock below it is therefore a few $\mathrm{cm}$ higher and serves as a kind of base (Fig. 7f). The development of the flutes stretches from the top of the rock across the bedding plane to the walls of the base. The flutes also dissect the upper edges of wider flat tops and the narrower parts of dissected rock. Below them are traces of water trickling on gently sloping surfaces (Fig. 8). From the ridge the flutes thus drain to the wall and to the flat top of the karren. They also occur on inclined sections of dissected surfaces of extensive and predominantly flat tops. They have already been dissected during the interbed formation (Fig. $7 \mathrm{~g}$ ), rarely by subsoil processes, and gradually by rainwater and sheet flow water (Fig. $7 \mathrm{~h}$ ). They are found at the edges of solution pans (Fig. 7d), steps formed by sheet flow water, and on the walls of funnellike mouths at the edge of the tops. From points they drain in a star-like formation (Fig. 7i). If exposed long enough to rain, the entire top of the karren gradually becomes dissected and covered with rain flutes. Flutes are therefore found everywhere on inclined rock surfaces where rain drops are in direct contact with the rock; on wider and more gently sloping and relatively 

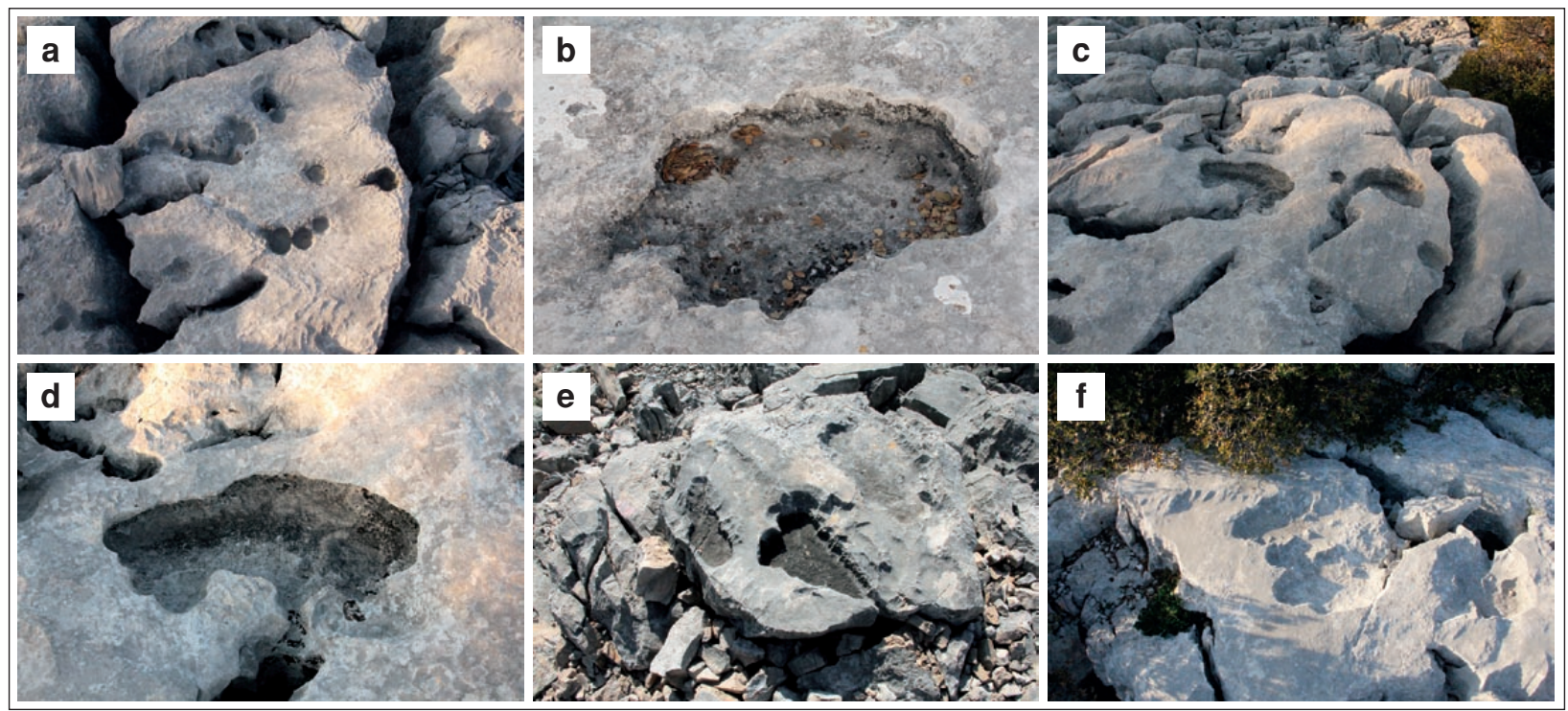

Fig. 9: Solution pans: a. solution pans, b. composite solution pan, c. solution pans, d., e. solution pan opened by channel, $f$. transformation of solution pan into steps.

flat tops, the decisive factors are the inclination and consequently the speed at which the water flows from the surface and the thickness of the water layer. Horizontal surfaces are dissected by rain pits (Figs. 3, 7j) that dominate on individual rocks. In places they dissect the bottoms of flutes. Under shrubs they develop into subsoil cups. Small cups about one $\mathrm{cm}$ in diameter form under shrubs due to water dripping from leaves and branches.

Rain channels (Figs. 3, 7k, 8e) also appear on longer and steeper walls, mostly on thicker rock strata, of the southwestern edge of the top.

On the relatively rapidly denuded, smooth, and only slightly inclined tops, the water flows rather evenly over the entire surface. Semi-circular steps form (Figs. 3; 8a, b, c, d, e, f; 9). They are up to $5 \mathrm{~cm}$ high and only rarely taller. Their diameters reach a decimeter in size. On steeper sections of the surface, they are higher and often connected, especially the largest, in transverse strings (Fig. 8a, c). They can be dissected by smaller steps. Such strings can exceed one meter in width. On larger gently sloping surfaces, the layer of water is relatively thick and rainwater does not fall directly on the rock. Rain flutes, from which water also flows onto lower-lying smooth surfaces (Slabe 2005), originally only occur at the upper edge of gently sloping surfaces, and later, when the small steps become larger, on their walls and higher lying sections of the surface as well (Fig. 8g). Channels (Figs. 3, 8h, 10) form on the run-off side under sharp edges and bends of a surface in which water flows on the walls, and funnel-shaped notches form at their mouths that in time become covered with flutes first on the upper sections and then, when enlarged, also on their walls (Slabe 2005).

Numerous solution pans are found (Figs. 3; 8a, $c, h ; 11)$ in various stages of development on flat tops. They develop from rain pits, denuded subsoil cups, and subsoil pits of interbed anastomoses after the upper stratum has disintegrated. Their diameters range from centimeters to decimeters in size (Fig. 9a). They have vertical or overhanging walls, and the deeper ones are found along fissures. Cups also occur on a lower stratum if distinct fissures cross the one above. Several solution pans can merge into one whose circumference is consequently semi-circular. Larger ones can be composite with many smaller solution pans (Fig. 9b) separated by ridges and points protruding from their bottoms. Rain flutes are found on the walls of larger solution pans. Solution pans often open with channels (Fig. 9c, d, e). On gently sloping surfaces they can transform into small steps, which at first take threequarter-circular shapes only to later open completely (Fig. 9f). At the edges of the tops they transform into a funnel-like notch.

The relatively dense overgrowth of shrubbery also influences the formation of the karren. The crevices are filled with soil, water drips from the shrubs, leaves are deposited on the rock and subsoil cups form under the weathered debris, and at the edge of the shrubbery the rock is more distinctly overgrown with lichen and moss.

\section{DEVELOPMENT OF KARREN}

On the Kamenjak hum, disintegration, especially of thinner strata, is a relatively fast process and thus karren ap- 
pear in various stages and forms of development. Parts of the karren were covered by soil and fissures were filled, and therefore traces of subsoil formation are preserved in places (Fig. 6). At the edges the karren are composed of smaller fragments of rock while the tops are sharpened into points or ridges (Fig. 4c, d, f, g). Steep walls are covered by rain flutes (Fig. 7a, b, d, e, i), and smaller flat tops by rain pits (Fig. 7j) and solution pans (Fig. 9). On the central parts of the karren that have flat and gently sloping tops, several development stages can be traced. After the denudation of the upper strata, the tops are smooth (Fig. 8a, b, c, d) or dissected with a network of channels (Fig. 8f) where anastomoses developed along the bedding planes or when they have pits that formed due to the percolation of water through the upper rock stratum. The latter two forms are relatively quickly dissected by a network of rain flutes (Fig. 7d). On the relatively smooth surfaces water flows evenly over the entire surface toward the edge where wall channels with funnel-like mouths form (Fig. 8h). The layer of water protects the rock from the direct impact of rainwater. Larger and smaller steps form (Fig. 8a, b, c, d, e). The flutes are therefore first found only at the upper edges (7c). In time, when the steps and solution pans are larger, their walls are also dissected by flutes (Fig. 7d). Channels begin to form among the network of flutes where the water drains from the flutes. Prior to this development, the water flows evenly from the flutes along the lower flat surface. Solution pans start to open. Flat surfaces can be dissected in a number of ways if their uncovering is gradual and if the upper stratum protects the lower stratum from the rain. Shelves with flutes on the walls start to form (Fig. 7f).

\section{CONCLUSION}

A typical example of karren development can be traced on the gently sloping rock strata. The karren have predominantly flat tops formed on the upper surfaces. The edges of the karren outcrop crumble into rocks fragments. The disintegration is more distinct on the lower edges of inclined rock strata.

The rock relief reveals all the significant development stages from subsoil formation to the dissolving and disintegration of the upper rock strata as well as the denuding and reshaping of newly uncovered rock surfaces. There are steps on denuded flat surfaces, traces of creeping sheets of water, and solution pans. Only their upper edges and the walls of the ledges are dissected by rain flutes. Over time, the walls of steps and solution pans also become dissected by flutes. A more distinct dissection by flutes and channels between them is observed on the tops whose surfaces have traces of interbed formation with anastomoses and the vertical percolation of water along fissures, i.e., on dissected surfaces. As a rule, the edges of strata have crumbled into numerous smaller rocks. These are sharp and dissected by rain flutes. Rain flutes are therefore found on the steeper and first denuded sections of the rock. The traces of subsoil formation are only preserved in the lower belts of karren.

The karren gradually become three-dimensionally dissected. Flat surfaces where steps dominate become dissected surfaces where rain flutes and channels are the most characteristic rock forms.

\section{ACKNOWLEDGEMENT}

The research was included in UNESCO IGCP project No. 598.

Article is also part of doctoral study of Ela Šegina and is partly co-financed by the European Union and by the European Social Fund respectively. The co-financing is carried out within the Human resources development operational programme for years 2007 - 2013, developmental priorities: Encouraging entrepreneurship and adaptation; preferential directives 1.3: scholarship schemes. 


\section{REFERENCES}

Engelhardt, W., Füchtbauer, H. \& G. Müller, 1964: Sediment-Petrologie, Methoden der Sediment-Untersuchung, Teil 1.- E. Schweizerbart'sche Verlagsbuchhandlung (Nägele u. Obermiller), pp. 303, Stuttgart. http://onlinelibrary.wiley.com/ doi/10.1002/iroh.19650500317/abstract

Evamy, B.D. \& D.J. Sherman, 1962: The application of chemical staining techniques to the study of diagenesis of limestones.- Proc. Geol. Soc. London, 1599, 102-103.

Fritz, F., 1978: Hidrogeologija Ravnih kotara i Bukovice.Krš Jugoslavije, 10, 1,1-43.

Fritz, F., 1984: Postanak i starost Vranskog jezera kod Biograda na moru (Origin and geological age of the Vrana Lake near Biograd na moru).- Geološki vjesnik, 37, 231-243.

Fritz, F., 1992: Effect of recent sea level change on development of karst phenomena.- Proceedings of the international symposium Geomorphology and Sea, Zagreb.

Horvatinčić, N., Roller-Lutz, Z. \& S. Kapelj, 2007: Application of isotope techniques in investigation of water resources and water protection in the Karst area of Croatia (IAEA TC CRO/8/006) (final report). DOI: $10.4154 / G C .2013 .13$

Kapelj, J., Kapelj, S. \& A. Pavičić, 2003: Tribute to knowledge of hydrogeological and hydrogeochemical relations in the catchment of Vransko lake and Vransko field.- Hydrological stabilization and conservation of biodiversity of the Vransko jezero Nature Park catchment area, Round table. Book of abstracts, 6-11. NPVJ prof. doc. archive, 77.

Magaš, D., 1990: Osnovna geografska obilježja Biogradske mikroregije. Biograd i njegova okolica $\mathrm{u}$ prošlosti.- In: Zbornik radova (̌̌. Batović, ed.), Zavod za povijesne znanosti Filozofskog fakulteta, Zadar, SIZ kulture općine Biograd, 39-84, Biograd.

Mamužić, P. 1971: Osnovna geološka karta Jugoslavije 1:100000, list Šibenik.- Geološki zavod, Zagreb, Savezni geološki zavod, Beograd.

Mišetić, S. \& M. Mrakovčić, 2003: Approach to defining ecologically acceptable flow (EAF) downstream from water barriers (Pristup definiranju ekološki prihvatljivog protoka (EPP) tekućica nizvodno od vodozahvata.- In: Hydrological stabilization and conservation of biodiversity of the Vransko jezero Nature Park catchment area (Hidrološka stabilizacija $i$ očuvanje biološke raznolikosti slivnog područja Parka prirode Vransko jezero), Round table. Book of abstracts, 20-25. NPVJ prof. doc. archive, 77.
Mrakovčić, M. et al., 2004: Kategorizacija i inventarizacija florističkih i faunističkih vrijednosti Parka prirode "Vransko jezero".- Studija, Javna ustanova Park prirode Vransko jezero, unpublished.

Perica, D., 1998: Geomorfologija krša Velebita.- Doctoral thesis, PMF, University of Zagreb.

Perica, D., \& T. Marjanac, 2009: Types of karren and their genesis on the Velebit mountain.- In: Ginés A. et al. (eds.) Karst rock features - Karren sculpturing, ZRC Publishing, 359-374, Ljubljana.

Perica, D., Marjanac, T. \& I. Mrak, 1999: Vrste grižina i njihov nastanak na području Velebita (Izvorni znanstveni članak).- Acta Geographica Croatica, 34, 1.

Perica, D., Marjanac, T., Ančić, B., Mrak, I. \& M. Juračić, 2004: Small karst features (karren) of Dugi otok Island and Kornati archipelago coastal karst (Croatia).- Acta carsologica, 33, 1, 117-130.

Rađa, T. \& S. Vujčić-Karlo, 2004: Biospeleološka istraživanja na širem području Parka prirode Vransko jezero.- Studija, Javna ustanova Park prirode Vransko jezero, unpublished.

Romić, D., M. Romić \& H. Bakić, 2009: Kvaliteta tala i monitoring površinskih voda u slivu Vranskog jezera; I faza - Kvaliteta tla. (The quality of soil and surface water monitoring in the basin of Vrana Lake, phase I - Soil quality.- Faculty of Agriculture, University of Zagreb, 108-128.

Rubić, I., 1936: Mali oblici na obalnom reljefu istočnog Jadrana.- Geografski vestnik, 12-13, 3-53, Ljubljana.

Slabe, T., 2005: Two experimental modelings of karst rock relief in plaster: subcutaneous "rock teeth" and "rock peaks" exposed to rain.- Z. Geomophol. N. F., 49, 107-119.

Slabe, T. \& H. Liu, 2009: Significant subsoil rock forms. In: Ginés A. et al. (eds.) Karst rock features - karren sculpturing, ZRC Publishing, 123-137, Ljubljana.

Stroj, A., 2012: Vransko jezero - Hidrogeološka istraživanja.- Hrvatski geološki institut, Zagreb, unpublished.

Šikić, Z., Pernar, N., Yerkovich, B. B., Rogošić, J. \& S. Širac, 2013: Influence of water levels of Vrana Lake and the Adriatic Sea to the water chemistry of Vrana lake.- Acta Adriat., 54, 2, 199-212.

Švonja, M., 2003: Hydrology of Vransko lake (Hidrologija Vranskog jezera), in Hydrological stabilization and conservation of biodiversity of the Vransko jezero Nature Park catchment area (Hidrološka stabilizacija i očuvanje biološke raznolikosti slivnog područja Parka prirode Vransko jezero).- Round table. Book of abstracts, 12-15. NPVJ prof. doc. archive, 77. 
Veress, M. \& K. Péntek, 2010: The development of hum slopes due to karren formation.- Karst development, Volume 1, Issue 2.

Žvorc, P. \& D. Hamidović, 2008: Inventarizacija faune šišmiša Parka prirode Vransko jezero.- Studija, Javna ustanova Park prirode Vransko jezero, unpublished.
Žvorc, P. \& D. Hamidović, 2010: Monitoring šišmiša u speleološkim objektima (špilja kod Vrane, Baldina i Banđenova jama) u Parku prirode Vransko jezero u razdoblju jesenskih migracija 2009. Godine.- Studija, Javna ustanova Park prirode Vransko jezero, unpublished. 